\title{
Comparison of insect biological diversity parameters in natural and degraded habitats in Gölcük Nature Park (Isparta, Turkey)
}

\author{
Gökhan Aydına,* id
}

\begin{abstract}
The study was carried out to compare the biodiversity parameters of the insect species in natural and un-natural habitats in Gölcük Nature Park (Isparta Province) between 2018 and 2019. Two natural and two unnatural habitats (impact of tourism) were selected to realize mentioned aim. Totally 40 pitfall traps (10 traps for each habitat) were set up to sample Coleoptera species. Species richness was found higher in natural habitats than unnatural ones. Diversity index (both Shannon-Wiener and Simpson) were calculated higher in natural habitats and as expected, dominancy inversely proportional to diversity was measured lower in natural habitats. Shannon Evenness, population density due to individual of the species showed mostly evenly distributed on the graphs in natural habitats. The Sörenson Coefficient results showed that selected natural and unnatural habitats groups were found similar to each other. The results of the study showed that human activity plays an important role in habitat destruction. It has been revealed that species richness and diversity are negatively affected in habitats with human impact.

Keywords: Coleoptera, Shannon-Wiener, Simpson, Sörenson, Evenness
\end{abstract}

\section{Gölcük Tabiat Parkın'da doğal ve bozulmuş habitatlarında böcek biyolojik çeşitlilik parametrelerinin karşılaştırılması (Isparta, Türkiye)}

\begin{abstract}
Özet: Çalışma, 2018-2019 yılları arasında Gölcük Tabiat Parkı'nda (Isparta İli) doğal ve doğal olmayan habitatlarda bulunan böcek türlerinin biyoçeşitlilik parametrelerinin karşılaştırılması amacıyla yapılmıştır. Bahsedilen amaca ulaşmak için iki doğal ve iki doğal olmayan (turizmin etkisi) orman ekosistemi seçilmiştir. Coleoptera türlerini örneklemek için toplam 40 adet çukur tuzak (her habitat için 10'ar adet) kurulmuştur. Çalışma sonunda doğal habitatlarda tür zenginliği doğal olmayanlara göre daha yüksek bulunmuştur. Çeşitlilik indeksi (hem Shannon-Wiener hem de Simpson) doğal habitatlarda daha yüksek hesaplanmış ve beklendiğ gibi, çeşitlilikle ters orantılı olan baskınlık, doğal olmayan habitatlarda daha yüksek ölçülmüştür. Shannon Evenness, popülasyon yoğunluk ilişkisi doğal yaşam ortamlarında çoğunlukla eşit dağılımlı grafikler oluşturmuştur. Sörenson katsayısı sonuçları, seçilen doğal ve doğal olmayan ekosistemlerin gruplar halinde birbirine benzer olduğunu göstermiştir. Çalışmanın sonuçları, insan faaliyetinin habitat tahribatında önemli bir rol oynadığını göstermiştir. İnsan etkisi ile habitatlarda tür zenginliği ve çeşitliliğinin olumsuz etkilendiği ortaya konmuştur.

Anahtar kelimeler: Coleoptera, Shannon-Wiener, Simpson, Sörenson, Evenness
\end{abstract}

\section{Introduction}

Turkey was formed by the coming together of the different geographical zones thus different habitats have enabled different animal and plant species to live there. That's why Turkey is the one of the most important areas in planet in terms of species richness as a natural consequence of this diversity (Aydin, 2006).

Gölcük Nature Park is the one of the six protected area in Isparta Province in Turkey. Gölcük Nature Park is located in Lakes Areas, Turkey's most important biodiversity areas, in the western part of Taurus. It is located on the transition zone between the Mediterranean and the terrestrial climate, and its altitude varies between 900-2000 meters. Extensive studies have been carried out in the Gölcük Nature Park in terms of plant diversity, but unfortunately almost no scientific study has been done in terms of insect diversity in this valuable area. Studies have shown that there are 227 species of plants belonging to 47 families in the mentioned protected area (Fakir and Dutkuner, 1999). However, the biodiversity values in these areas are negatively affected due to the richness of species that have recently been destroyed by human activity.

In this study, the habitats of human activity were compared with natural similar ones, and the reasons for the difference between natural and destructed habitats were discussed by calculating the biological diversity parameters.

\section{Materials and methods}

\subsection{Study areas}

This study was carried out in Gölcük Nature Park from May to September between 2018 and 2019. The habitats dominated by with Pinus nigra Arn. subsp. pallasiana (Lamb.) Holmboe were chosen as study area. Two natural $\bowtie$ a Isparta Uygulamalı Bilimler Üniversitesi, Atabey Meslek Yüksekokulu, Atabey Isparta, Türkiye

@ * Corresponding author (İletişim yazarı): gokhanaydin@isparta.edu.tr

$\checkmark \quad$ Received (Geliş tarihi): 07.10.2021, Accepted (Kabul tarihi): 20.11.2021
Citation (Atıf): Aydın, G., 2021. Comparison of insect biological diversity parameters in natural and degraded habitats in Gölcük Nature Park (Isparta, Turkey). Turkish Journal of Forestry, 22(4): 362-365. DOI: $10.18182 /$ tjf.1006039 
(NF_1, NF_2) and two unnatural habitat (effected of tourism) (UnNF_1, UnNF_2) were selected to compare differentiation of habitats.

\subsection{Sampling method}

Totally 40 pitfall traps (10 traps for each habitat) are placed in all habitat. Plastic containers of approximately 15 $\mathrm{cm}$ in diameter and $20 \mathrm{~cm}$ in depth were buried in the soil in habitats, with 10 pieces at 10 meters intervals, with the open parts at the soil level (New, 1998). Biodiversity parameters were calculated with the data obtained from pitfall traps. Sampled insects that fell into pitfall traps were killed with the help of a killing bottle and brought to the "Insect Biodiversity Laboratory" in Isparta University of Applied Sciences, Atabey Vocational School for labelling, pinning, and counting. Distinctions were made on the basis of family, genus and species level.

\subsection{Measurement of biological diversity parametres}

Biodiversity basic parameters of habitats were calculated using the EvenDiv 1.1 program (Heimann, 2004), the parameters used and their calculation methods are given below:

Shannon-Wiener and Simpson diversity indices were used to determine species diversity.

- Shannon-Wiener diversity index (H')

$$
H^{\prime}=-\sum p_{i} \ln \left(p_{i}\right)
$$

where $\mathrm{H}^{\prime}$ is the index of diversity, pi is the importance value of a species as a proportion of all species, and $\ln$ is the natural logarithm

- Simpson diversity index (S)

$$
S=1-\sum n_{i}\left(n_{i}-1\right) / N(N-1)
$$

where $\mathrm{S}$ is the index of diversity, ni is the importance value of a species as a proportion of all species, and $\mathrm{N}$ is the sum of the number of individuals (Magurran, 1988; Magurran, 2004; Özkan, 2016).

Simpson dominancy index was used to determine dominance

- Simpson's dominance index $(\mathrm{Sd})$

$$
S d=\sum n_{i}\left(n_{i}-1\right) / N(N-1)
$$

where $\mathrm{Sd}$ is the index of dominancy, $\mathrm{i}$ is number of species, ni is the importance value of a species as a proportion of all species, and $\mathrm{N}$ is the sum of the number of individuals

Shannon Evenness and Simpson Evenness index were used to determine population density relationships of the species.

- Shannon evenness index (EH)

$$
\left.E H=H^{\prime} / \ln (N)\right)
$$

where EH is Evenness index, H' is the index of ShannonWiener diversity, $\mathrm{ln}$ is the natural logarithm, and $\mathrm{N}$ is the sum of the number of individuals.

- Simpson Evenness index (Esm) where Esm is Simpson Evenness, $\mathrm{S}$ is Simpson diversity, $\mathrm{N}$ is species richness (Magurran, 1988 ve 2004; Özkan, 2016).

Percentage similarity index (Bs) was used to determine the compositional similarity between the habitats

- Percent similarity

$$
\% S=\sum \min (a, b, \ldots ., x)
$$

where $\% \mathrm{~S}$ is percent similarity, $\sum \mathrm{min}$ is the sum of the smallest values whose percentages are calculated in the habitat with the smallest values in the other habitat whose similarity is calculated (Kreps, 1999).

Multi Variate Statistical Package (MVSP) 3.11c program was used to classify selected habitats (Kovach, 1999).

The identification of the insects sampled at the family level is carried out by Borror et al. (1981). Insects diagnosed at the family level were identified at the "morpho-species" level (Lodge and Cantrell, 1995; Clauson, 2002, Ryder et al., 2005; Borgelt and New, 2006; Dudgeon, 2006; Yanoviak et al., 2006; Grimbacher and Stork, 2007).

\section{Results}

During the study, 1544 individuals belonging to 50 species from 13 different families under Coleoptera were sampled (see appendix). Species richness were found much higher in natural habitats than habitat under tourism activity in both study years (Table 1). The most individuals were collected in NF_2 with 218 and 264 in 2018 and 2019, respectively. Shannon-Wiener were found the highest values in natural habitats in both NF_1 and NF_2 with 3.39 and 3.46 in 2018 and 3.49 and 3.52 in 2019. Simpson diversity index gave similar results around $0.96 \pm 1$ in both study years (Table $1)$.

Table 1. Biodiversity parameter values calculated with the

\begin{tabular}{|c|c|c|c|c|}
\hline & \multicolumn{4}{|c|}{2018} \\
\hline & NF_1 & NF_2 & UnNF_1 & UnNF_2 \\
\hline No. of Species & 39 & 41 & 28 & 28 \\
\hline No. of Individuals & 185 & 218 & 130 & 141 \\
\hline \multicolumn{5}{|l|}{ Diversity indices } \\
\hline Shannon-Wiener[H] & 3.3956 & 3.4602 & 2.9276 & 2.7147 \\
\hline Simpson Index[D] & 0.0426 & 0.0393 & 0.0755 & 0.1065 \\
\hline Simpson Diversity[1-D] & 0.9574 & 0.9607 & 0.9245 & 0.8935 \\
\hline \multicolumn{5}{|l|}{ Evenness indices } \\
\hline Shannon-Evenness[EH] & 0.9269 & 0.9318 & 0.8786 & 0.8147 \\
\hline \multirow{2}{*}{ Simpson-Evenness [E1/D] } & 0.6019 & 0.6206 & 0.473 & 0.3353 \\
\hline & \multicolumn{4}{|c|}{2019} \\
\hline No. of Species & 43 & 43 & 29 & 30 \\
\hline No. of Individuals & 206 & 264 & 187 & 213 \\
\hline Diversity indices & & & & \\
\hline Shannon-Wiener[H] & 3.4992 & 3.5296 & 3.0025 & 2.8112 \\
\hline Simpson Index[D] & 0.0415 & 0.035 & 0.0715 & 0.0991 \\
\hline Simpson Diversity[1-D] & 0.9585 & 0.9650 & 0.9285 & 0.9009 \\
\hline Evenness indices & & & & \\
\hline Shannon-Evenness[EH] & 0.9303 & 0.9384 & 0.8917 & 0.8265 \\
\hline Simpson-Evenness [E1/D] & 0.5604 & 0.6645 & 0.4823 & 0.3364 \\
\hline
\end{tabular}
data obtained from the pitfall trap sampling method in Natural Pinus nigra Forest (NF_1 and NF_2) and un-natural Pinus nigra Forest effected by tourism activity (UnNF_1 and UnNF_2) between 2018 and 2019.
$\mathrm{Esm}=\mathrm{S} / \mathrm{N}$ 
In contrast to diversity, dominance values were found higher in habitats with tourism activity. Result of the Evenness index, both Shannon and Simpson, showed that individual of the species living in natural habitats were more balanced distribution than un-natural ones although obtained values were found close to each other (Table 1).

Similarity index found that naturally selected habitats (NF_1 and NF_2) have higher similarities to each other than unnatural habitats (UnNF_1 and UnNF_2) during the first study year while un-naturel habitats were found more similar than natural ones in 2019 (Figure 1).

\section{Discussion}

The reason why the species richness and other biodiversity values measured in habitats that have been exposed to human activity for a long time can be measured lower when compared to natural habitats can be explained the displacement of the species and the increase and decrease of their populations (Aydin et al., 2005; Aydin and Kazak, 2007 ve 2010; Aydin and Karaca, 2011; Aydin, 2018). In this study, although the biodiversity measurement results show high biodiversity values in natural habitats, the biodiversity and evenness calculated values in unnatural habitats are found to be close to each other, which cannot be underestimated.

The present study showed that the habitat changes due to tourism activities had changed not only to the insect diversity but also to their structure within communities (see appendix). Many scientific studies showed similar results (Morris, 2010; Sutrisno, 2010; Barron et al., 2019; Forister et al., 2019).

Similarity results showed different results in both years. This is because the study was conducted for only two years. Long-term biological diversity measurements in the same habitats are necessary to obtain results that can explain the reason for the difference.
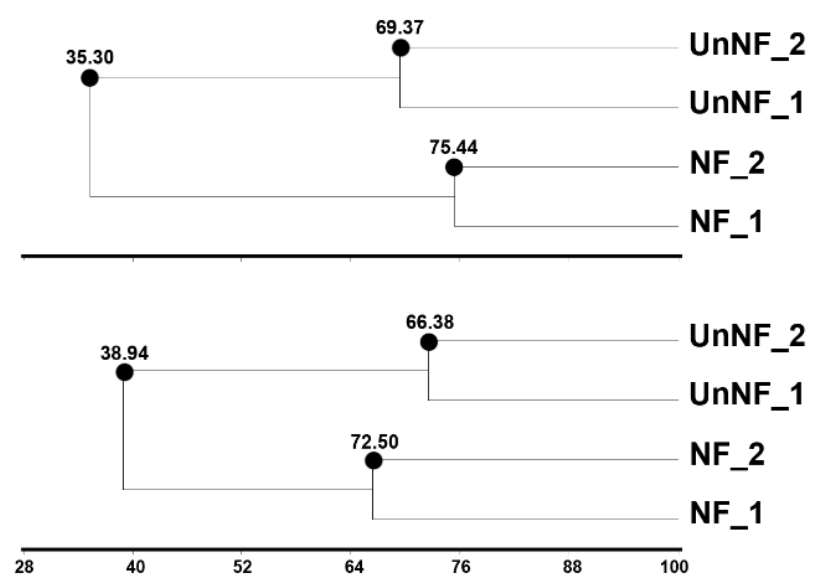

Figure 1. Percentage similarity classification analysis calculated considering the insect species sampled in Natural Pinus nigra Forest (NF_1 and NF_2) and un-natural Pinus nigra Forest effected by tourism activity (UnNF_1 and UnNF_2) (UPGMA: Unweighted Pair Group with Arithmetic Mean) * 2018 upper; 2019 bottom.

\section{Conclusion}

Biodiversity parameter values to be measured each year in order to ensure the sustainability of protected areas may indicate whether the habitats are degraded or not. Even though insects are not used frequently in the sustainability of protected areas, benefit can be gained by selecting insect groups that sustain their lives on the soil surface such as Carabidae, Tenebrionidae, Scarabaeidae, Staphylinidae, etc. and have high potential to be used as biological indicators.

The use of insect species in habitat protection can be achieved by using them as a single indicator, as well as by considering insect assemblages as a whole. This can be achieved by periodically measuring biological diversity parameters in order to carry protected areas into the future.

\section{References}

Aydın, G., Sekeroglu, E., Arndt, E., 2005. Tiger beetles as bioindicators of habitat degradation in the Çukurova Delta, Southern Turkey (Coleoptera: Cicindelidae). Zoology in the Middle East, 36: 51-58.

Aydın, G., 2006. Çukurova Deltası'nda böceklerin sürdürülebilir alan kullanımında biyolojik gösterge olarak değerlendirilme olanakları. Doktora tezi. Çukurova Üniversitesi, Fen Bilimleri Enstitüsü, Adana.

Aydın, G., Kazak, C., 2007. Çukurova Deltası (Adana) biyotoplarında böceklerin farklı insan aktivitelerine biyolojik gösterge olarak kullanılma olanakları. Türk.Entomol.Dergisi, 31 (2):111-128.

Aydın, G., Kazak, C., 2010. Selecting indicator species habitat description and sustainable land utilization: A case study in a Mediterranean Delta. International Journal of Agriculture \& Biology, 12(6): 931-934

Aydın, G., Karaca, İ., 2011. Human threats to population of endemic sand dune cricket (Schizodactylus inexpectatus). International Journal of Agriculture \& Biology, 13(6): 1016-1020.

Aydın, G., 2018. Determination of indicator species in coastal successions in Tentsmuir National Nature Reserves (NNR), Scotland. Fresenius Environmental Bulletin. 27 (7): 5037-5044.

Barron, M.C., Liebhold, A.M, Kean, J.M., Richardson, B., Brockerhoff, E.G., 2019. Habitat fragmentation and eradication of invading insect herbivores. Journal of Applied Ecology, 57 (3): 590-598.

Borgelt, A., New, T.R., 2006. Pitfall trapping for ants (Hymenoptera, Formicidae) in mesic Australia: what is the best trapping period? Journal of Insect Conservation: 10: 75-77.

Borror, D.J., Delong M.D., Triplehorn, C.A., 1981. An introduction to the study of insects. Fifth edition Sounders Collelege Publishing, Philadelphia.

Clauson, D., 2002. III. Environmental Restoration. Restoration's Influence on Aerial Arthropod Diversity - Damien Clauson (John Latto, Matt Orr, Justin Remais and Manish Desai, (Editors) Senior Research Seminar Environmental Sciences Group Major University of California at Berkeley Berkeley, California. 9 p.

Dudgeon, D., 2006. The impacts of human disturbance on stream benthic invertebrates and their drift in North Sulawesi, Indonesia. Freshwater Biology, 51: 1710-1729.

Fakir, H, Dutkuner, İ., 1999. Isparta Gölcük Tabiat Parkı Florası üzerine araştırmalar. 1st International Symposium on Protection of Natural Environment and Ehrami Karaçam, 23-25 September, Kütahya-Türkiye, pp. 77-87.

Forister, M.L., Pelton, E.M., Black, S.H., 2019. Declines in insect abundance and diversity: We know enough to act now. Conservation Science and Practice. 1 (8): 1-8

Grimbacher, P.S., Stork, N.E., 2007. Vertical stratification of feeding guilds and body size in beetle assemblages from an Australian tropical rainforest. Austral Ecology, 32: 77-85. 
Heimann, D., 2004. EvenDiv 1.1. Based on a DBase Program Code Supplied by Jörg Perner and Martin Schnitter. Institute of Ecology, University of Jena.

Kovach, W.L., 1999. A Multi variate Statistical Package. United Kingdom: Kovach Computing Services.

Krebs, C.J., 1999. Ecological Methodology. An Imprint of Addison Wesley Longman, Inc.

Lodge, D.J., Cantrell, S., 1995. Diversity of litter agarics at cuyabeno, Ecuador: calibrating sampling efforts in tropical rainforest. Mycologist, 9 (4): 149-151.

Magurran, A.E., 1988 Ecological Diversity and Its Measurement. Princeton University Press, Princeton, NJ.

Magurran, A.E., 2004. Measuring Biological Diversity. Blackwell Science Ltd.

Morris, R.J., 2010. Anthropogenic impacts on tropical forest biodiversity: a network structure and ecosystem functioning perspective. Philos Trans R Soc Lond B Biol Sci., 365(1558): 3709-3718.
New, T.R., 1998. Invertebrate Surveys for Conservation. Oxford University Press.

Özkan, K., 2016. Biyolojik Çeşitlilik Bileşenleri Nasıl Ölçülür? Süleyman Demirel Üniversitesi Orman Fakültesi Yayınları, Yayın No: 98, Isparta.

Ryder, C., Moran J., MC Donnell, R., Gormally, M., 2005. Conservation implications of grazing practices on the plant and dipteran communities of a turlough in Co. Mayo, Ireland. Biodiversity and Conservation, 14: 187-204.

Sutrisno, H., 2010. The impact of human activities to dynamic of insect communities: A case study in Gunung Salak, West Java. Hayati Journal of Biosciences, 17 (4): 161-166.

Yanoviak, S.P., Nadkarni, N.M., Solano, J.R., 2006. Arthropod Assemblages in Epiphyte Mats of Costa Rican Cloud Forests. Biotropica, 36(2): 202-210.

Appendix. The list of Coleoptera species sampled by pitfall traps during 2018 and 2019 in Gölcük Nature Park in Isparta, Turkey.

\begin{tabular}{|c|c|c|c|c|c|}
\hline Family & Species & NF_1 & NF_2 & UnNF_1 & UnNF_2 \\
\hline Apionidae & Apion sp. Herbst, 1797 & 10 & 6 & 0 & 0 \\
\hline \multirow[t]{4}{*}{ Buprestidae } & Anthaxia diadema (Fischer von Waldheim, 1824) & 0 & 1 & 3 & 3 \\
\hline & Capnodis miliaris (Klug, 1829) & 3 & 0 & 6 & 10 \\
\hline & Julodis ehrenbergii Laporte, 1835 & 4 & 9 & 27 & 10 \\
\hline & Trachypteris picta (Pallas, 1773) & 3 & 5 & 7 & 9 \\
\hline \multirow[t]{20}{*}{ Carabidae } & Abax sp. Bonelli, 1810 & 16 & 22 & 0 & 0 \\
\hline & Abax sp. Bonelli, 1810 & 2 & 0 & 0 & 0 \\
\hline & Amara sp. Bonelli, 1810 & 13 & 11 & 0 & 0 \\
\hline & Amara sp. Bonelli, 1810 & 6 & 3 & 47 & 71 \\
\hline & Amara sp. Bonelli, 1810 & 2 & 1 & 0 & 1 \\
\hline & Acinopus sp. Dejean, 1821 & 12 & 27 & 5 & 10 \\
\hline & Agonum sp. Bonelli, 1810 & 5 & 8 & 5 & 7 \\
\hline & Carabus cribratus (Motschulsky, 1850) & 9 & 19 & 7 & 3 \\
\hline & Carabus glabratus Paykull, 1790 & 50 & 39 & 0 & 0 \\
\hline & Carabus graecus Dejean, 1826 & 20 & 39 & 11 & 5 \\
\hline & Carabus gotschii Chaudoir, 1846 & 7 & 11 & 0 & 0 \\
\hline & Carabus scabripennis Chaudoir, 1850 & 12 & 20 & 0 & 0 \\
\hline & Carabus tenuitarsis (Kraatz, 1877) & 3 & 8 & 3 & 5 \\
\hline & Carabus victor Fischer von Waldheim, 1836 & 14 & 15 & 4 & 5 \\
\hline & Harpalinus sp. Jeannel, 1946 & 7 & 17 & 4 & 7 \\
\hline & Lamprostus torosus (I.Frivaldszky von Frivald, 1835) & 12 & 11 & 0 & 0 \\
\hline & Pachystus sp. Motschoulsky, 1865 & 9 & 17 & 0 & 0 \\
\hline & Pachystus graecus (Dejean, 1826) & 8 & 10 & 7 & 6 \\
\hline & Procrustes anatolicus Chaudoir, 1857 & 13 & 13 & 0 & 0 \\
\hline & Procerus scabrosus (A.G.Olivier, 1790) & 5 & 7 & 11 & 3 \\
\hline \multirow[t]{2}{*}{ Cerambycidae } & Cerambyx sp. Linnaeus, 1758 & 0 & 4 & 8 & 7 \\
\hline & Stictoleptura excisipes (K.Daniel \& J.Daniel, 1891) & 0 & 4 & 5 & 10 \\
\hline Cetoniidae & Cetonia aurata (Linnaeus, 1758) & 11 & 14 & 18 & 11 \\
\hline \multirow[t]{5}{*}{ Chrysomelidae } & Chrysolina herbacea (Duftschmid, 1825) & 9 & 14 & 11 & 3 \\
\hline & Chrysomela populi Linnaeus, 1758 & 3 & 0 & 0 & 4 \\
\hline & Cryptocephalus duplicatus Suffrian, 1845 & 0 & 3 & 0 & 0 \\
\hline & Cryptocephalus flavipes Fabricius, 1781 & 1 & 0 & 1 & 0 \\
\hline & Labidostomis sp. Germar, 1817 & 7 & 3 & 0 & 0 \\
\hline Cicindelidae & Cicindela campestris Linnaeus, 1758 & 7 & 8 & 0 & 0 \\
\hline \multirow[t]{3}{*}{ Coccinellidae } & Adalia bipunctata (Linnaeus, 1758) & 7 & 5 & 0 & 0 \\
\hline & Coccinella septempunctata Linnaeus, 1758 & 15 & 7 & 15 & 47 \\
\hline & Exochomus quadripustulatus (Linnaeus, 1758) & 7 & 9 & 11 & 5 \\
\hline \multirow[t]{4}{*}{ Curculionidae } & Larinus onopordi (Fabricius \& J.C., 1787) & 6 & 0 & 0 & 0 \\
\hline & Otiorhynchus sp. Germar, 1822 & 9 & 13 & 7 & 16 \\
\hline & Phyllobius incanus Gyllenhal, 1834 & 5 & 11 & 0 & 0 \\
\hline & Sitona macularius (Marsham, 1802) & 0 & 0 & 5 & 9 \\
\hline \multirow[t]{3}{*}{ Melolonthidae } & Anoxia asiatica Desbrochers, 1871 & 14 & 18 & 14 & 5 \\
\hline & Melolontha melolontha (Linnaeus, 1758) & 8 & 4 & 9 & 7 \\
\hline & Polyphylla fullo (Linnaeus, 1758) & 0 & 7 & 4 & 2 \\
\hline Scarabaeidae & Scarabaeus sacer Linnaeus, 1758 & 4 & 8 & 50 & 64 \\
\hline \multirow[t]{3}{*}{ Scolytidae } & Blastophagus minor (Hartig, 1834) & 7 & 0 & 0 & 0 \\
\hline & Blastophagus piniperda Eichhoff, $1864 \mathrm{~b}$ & 1 & 5 & 5 & 3 \\
\hline & Ips sp. De Geer, 1775 & 5 & 10 & 7 & 6 \\
\hline \multirow[t]{2}{*}{ Tenebrionidae } & Colpotus vogti Koch, 1944 & 0 & 7 & 0 & 0 \\
\hline & Tenebrio sp. Linnaeus, 1758 & 20 & 9 & 0 & 0 \\
\hline
\end{tabular}

